\title{
Features of the Development of the World Oil Market in Conditions of Coronavirus Pandemic
}

\author{
Elena Kovaleva \\ Department of World Economy \\ Belgorod State National Research \\ University \\ Belgorod, Russia \\ EKovaleva@bsu.edu.ru
}

\author{
Artem Seminog \\ Faculty of World Economy and \\ International Affairs \\ National Research University Higher \\ School of Economics \\ Moscow, Russia \\ artemiy-seminog@mail.ru
}

\author{
Margarita Mkhitaryan \\ Department of World Economy \\ Belgorod State National Research \\ University \\ Belgorod, Russia \\ mkhitaryan@bsu.edu.ru
}

\begin{abstract}
This article considers the features of the world oil market development in modern conditions. The world oil markets significantly affected by uneconomic factors in particular pricing processes, primarily political ones. Economists predicted the beginning of the global economic crisis in 2020. The coronavirus pandemic has also been added to the main and traditional causes of the economic crisis, such as cyclicity of economy, declining of economic growth rates and falling of financial market indicators, which has affected all spheres of society. The impact of coronavirus on the world oil market is determined by the correlation- regression analysis: the price of oil has acquired a high negative dependence upon the number of newly infected with coronavirus; the dependence of price of Brent oil on the number of new infected COVID-19 is semilogarithmic. This article defines the significant impact of the coronavirus pandemic on the world oil market, which is expressed in a decrease in demand, a reduction in production rates and will primarily affect oil-producing countries that are forced to transform their economies in these conditions.
\end{abstract}

Keywords-energy resources, world oil market, oil price, coronavirus pandemic, correlation-regression analysis

\section{INTRODUCTION}

Many economists predicted the onset of the global economic crisis just in 2020. Record values of indices indicated that the economy is overheating and the impending stage of recession both on the world stock exchange (Dow Jones Index, S\&P 500) and on the Russian financial market (RTS and MICEX Indices). But no one could have imagined that this recession would arrive under the wing of a real "black Swan", so named coronavirus pandemic COVID-19 that broke out in the Chinese city of Wuhan and then spread around the world.

Quarantine measures, massively introduced in many countries, have suspended business processes in many areas, from tourism and entertainment to wholesale of certain types of products. According to the April forecasts of the IMF, the world economy will miss $3 \%$ of GDP or 2.6 trillion US dollars in 2020 due to the outbreak of COVID-19 [4]. The oil and gas industry will also face big losses. The price of a barrel of Brent dropped by $67 \%$ over the three quarantine months, from $60 \$$ to $20 \mathrm{\$}$. Of course, the fall in price is largely due to the oversupply that prevailed even before the crisis began. However, the impact of coronavirus on oil prices cannot be denied either.

\section{METHODOLOGY}

As part of this study, it was decided to test the impact of coronavirus on the global oil market using correlation and regression analysis. The economic and statistical research method was chosen due to the fact that it can be used to unambiguously determine the presence or absence of a relationship between various parameters.

Taking into account the fact that quarantine measures due to the need to contain the spread of infection objectively lead to a decrease in demand for energy resources, all other things being equal, the price of oil should go down. Let's put forward the following hypothesis: there is a noticeable inverse relationship between the rate of spread of the coronavirus and the price of oil. Average (moderate) in this study is considered a correlation from 0,5 to 0,7 on the Chaddock scale.

To conduct a qualitative analysis, statistics were collected for more than three months (Table 1). The starting point for the analysis was January 20, since it was on this day that the first cases of infection not outside China (South Korea, USA) became known. In addition, it was on January 20, 2020 that China officially confirmed that the virus is transmitted from person to person even before the onset of symptoms of the disease during the incubation period.

TABLE I. INITIAL DATA FOR THE CORRELATION AND REGRESSION ANALYSIS

\begin{tabular}{|c|c|c|}
\hline \multirow{2}{*}{ Data } & $\begin{array}{c}\text { Brent 1 oil price, } \\
\text { USD/ barrel }\end{array}$ & $\begin{array}{c}\text { Number of new cases of } \\
\text { coronavirus infection }{ }^{2}, \text { units }\end{array}$ \\
\cline { 2 - 3 } & $\boldsymbol{y}$ & $\boldsymbol{x}$ \\
\hline 21.01 .2020 & 64,59 & 151 \\
\hline 22.01 .2020 & 63,21 & 133 \\
\hline
\end{tabular}




\begin{tabular}{|c|c|c|}
\hline \multirow{2}{*}{ Data } & $\begin{array}{c}\text { Brent } 1 \text { oil price, } \\
\text { USD/ barrel }\end{array}$ & $\begin{array}{l}\text { Number of new cases of } \\
\text { coronavirus infection }{ }^{2} \text {, units }\end{array}$ \\
\hline & $y$ & $x$ \\
\hline 23.01 .2020 & 62,04 & 265 \\
\hline 24.01 .2020 & 59,89 & 468 \\
\hline 25.01 .2020 & 59,89 & 703 \\
\hline 26.01 .2020 & 58,69 & 786 \\
\hline 27.01 .2020 & 58,58 & 1778 \\
\hline 28.01 .2020 & 58,81 & 1482 \\
\hline 29.01 .2020 & 58,91 & 1755 \\
\hline 30.01 .2020 & 57,33 & 1994 \\
\hline 31.01 .2020 & 56,62 & 2134 \\
\hline 01.02 .2020 & 56,62 & 2609 \\
\hline 02.02 .2020 & 55,66 & 2277 \\
\hline 03.02 .2020 & 54,45 & 3111 \\
\hline 04.02 .2020 & 53,96 & 3992 \\
\hline 05.02 .2020 & 55,28 & 3717 \\
\hline 06.02 .2020 & 54,93 & 3210 \\
\hline 07.02 .2020 & 54,47 & 3076 \\
\hline 08.02 .2020 & 54,47 & 3223 \\
\hline 09.02 .2020 & 53,96 & 3421 \\
\hline 10.02 .2020 & 53,27 & 2214 \\
\hline 11.02 .2020 & 54,01 & 2050 \\
\hline 12.02 .2020 & 55,79 & 15135 \\
\hline 13.02 .2020 & 56,34 & 4220 \\
\hline 14.02 .2020 & 57,32 & 2728 \\
\hline 15.02 .2020 & 57,32 & 2146 \\
\hline 16.02 .2020 & 57,12 & 2185 \\
\hline 17.02 .2020 & 57,67 & 2029 \\
\hline 18.02 .2020 & 57,75 & 1878 \\
\hline 19.02 .2020 & 58,72 & 532 \\
\hline 20.02 .2020 & 58,80 & 532 \\
\hline 21.02 .2020 & 57,94 & 1072 \\
\hline 22.02 .2020 & 57,94 & 1359 \\
\hline 23.02 .2020 & 56,33 & 357 \\
\hline 24.02 .2020 & 55,77 & 784 \\
\hline 25.02 .2020 & 54,26 & 645 \\
\hline 26.02 .2020 & 52,81 & 964 \\
\hline 27.02 .2020 & 51,73 & 1407 \\
\hline 28.02 .2020 & 49,67 & 1368 \\
\hline 29.02 .2020 & 49,67 & 2414 \\
\hline 01.03 .2020 & 49,41 & 1802 \\
\hline 02.03 .2020 & 51,90 & 1927 \\
\hline 03.03 .2020 & 51,86 & 1837 \\
\hline 04.03 .2020 & 51,13 & 2950 \\
\hline
\end{tabular}

\begin{tabular}{|c|c|c|}
\hline \multirow[t]{2}{*}{ Data } & $\begin{array}{c}\text { Brent } 1 \text { oil price, } \\
\text { USD/ barrel }\end{array}$ & $\begin{array}{l}\text { Number of new cases of } \\
\text { coronavirus infection }{ }^{2} \text {, units }\end{array}$ \\
\hline & $y$ & $x$ \\
\hline 05.03 .2020 & 49,99 & 2672 \\
\hline 06.03 .2020 & 45,27 & 3851 \\
\hline 07.03 .2020 & 45,27 & 4254 \\
\hline 08.03 .2020 & 35,93 & 3886 \\
\hline 09.03 .2020 & 35,79 & 4170 \\
\hline 10.03.2020 & 37,44 & 5204 \\
\hline 11.03 .2020 & 35,67 & 7133 \\
\hline 12.03 .2020 & 33,22 & 9526 \\
\hline 13.03 .2020 & 35,44 & 5617 \\
\hline 14.03 .2020 & 35,44 & 12562 \\
\hline 15.03 .2020 & 34,58 & 9648 \\
\hline 16.03 .2020 & 31,41 & 18220 \\
\hline 17.03 .2020 & 30,45 & 12820 \\
\hline 18.03.2020 & 28,76 & 23746 \\
\hline 19.03.2020 & 30,43 & 27908 \\
\hline 20.03 .2020 & 29,00 & 29673 \\
\hline 21.03 .2020 & 29,00 & 31703 \\
\hline 22.03 .2020 & 28,16 & 35692 \\
\hline 23.03 .2020 & 29,82 & 36086 \\
\hline 24.03 .2020 & 29,82 & 42584 \\
\hline 25.03 .2020 & 29,98 & 50285 \\
\hline 26.03 .2020 & 29,22 & 60433 \\
\hline 27.03 .2020 & 27,95 & 53507 \\
\hline 28.03 .2020 & 27,95 & 82085 \\
\hline 29.03 .2020 & 26,85 & 53953 \\
\hline 30.03 .2020 & 26,42 & 62650 \\
\hline 31.03 .2020 & 26,35 & 73877 \\
\hline 01.04 .2020 & 24,74 & 77146 \\
\hline 02.04 .2020 & 29,94 & 79511 \\
\hline 03.04 .2020 & 34,11 & 83569 \\
\hline 04.04 .2020 & 34,11 & 101922 \\
\hline 05.04 .2020 & 31,70 & 67957 \\
\hline 06.04 .2020 & 33,05 & 75790 \\
\hline 07.04 .2020 & 31,87 & 82353 \\
\hline 08.04 .2020 & 32,84 & 83994 \\
\hline 09.04 .2020 & 31,48 & 90805 \\
\hline 10.04 .2020 & 31,48 & 98264 \\
\hline 11.04 .2020 & 31,48 & 79652 \\
\hline 12.04 .2020 & 34,08 & 74043 \\
\hline 13.04 .2020 & 31,74 & 71272 \\
\hline 14.04 .2020 & 29,60 & 70918 \\
\hline 15.04 .2020 & 27,69 & 90281 \\
\hline
\end{tabular}




\begin{tabular}{|c|c|c|}
\hline \multirow{2}{*}{ Data } & $\begin{array}{c}\text { Brent 1 oil price, } \\
\text { USD/ barrel }\end{array}$ & $\begin{array}{c}\text { Number of new cases of } \\
\text { coronavirus infection }{ }^{2} \text { units }\end{array}$ \\
\cline { 2 - 3 } & $\boldsymbol{y}$ & $\boldsymbol{x}$ \\
\hline 16.04 .2020 & 27,82 & 76216 \\
\hline 17.04 .2020 & 28,08 & 87065 \\
\hline 18.04 .2020 & 28,08 & 81123 \\
\hline 19.04 .2020 & 27,73 & 58144 \\
\hline 20.04 .2020 & 25,57 & 92112 \\
\hline 21.04 .2020 & 19,33 & 74306 \\
\hline 22.04 .2020 & 20,37 & 79961 \\
\hline 23.04 .2020 & 21,33 & 85005 \\
\hline 24.04 .2020 & 21,44 & 111036 \\
\hline 25.04 .2020 & 21,44 & 88094 \\
\hline
\end{tabular}

Source: "Dynamics of the price of Brent crude oil for 2020", Calculator reference portal, 20002020, URL: https://www.calc. ru/dinamika-Brent.html?date $=2020132$ Coronavirus website (COVID -19), 2020, URL: https://coronavirus-monitor.ru/statistika/

The first part of this study is regression analysis. The parameter $y$ - the dependent or explained variable - in the regression model was the price of Brent crude, expressed in US dollars. The daily number of new cases of corona virus infection was chosen as the explanatory variable $\mathrm{x}$. It was decided to start the study with linear regression modeling $(y=$ $a+b x)$. The value of the $y$ parameter at the reporting point was 65 . The number of people infected with COVID-19, in turn, by January 20 was 217 people. The results of the regression analysis carried out using MS Excel are shown in figure 1.

\begin{tabular}{|c|c|c|c|c|c|}
\hline \multicolumn{2}{|c|}{ Regression statistics } & & & & \\
\hline Multiple R & 0,814797862 & & & & \\
\hline R-square & 0,663895556 & & & & \\
\hline $\begin{array}{l}\text { Normal } \\
\text { square }\end{array}$ & 0,660319977 & & & & \\
\hline Std.mistake & 7,92180509 & & & & \\
\hline Observation & 96 & & & & \\
\hline \multicolumn{6}{|c|}{ Anaysis of variance } \\
\hline & df & sS & MS & $F$ & $F$ \\
\hline Regression & 1 & 11652,03192 & 11652,03192 & 185,674969 & $\begin{array}{l}5,56 \mathrm{E}- \\
24\end{array}$ \\
\hline The remainder & 94 & 5898,969614 & 62,75499589 & & \\
\hline \multirow[t]{2}{*}{ Total } & 95 & 17551,00153 & & & \\
\hline & Contef. & Artmistake & t-stat. & $P-\ldots \ldots$ & \\
\hline Y-intersection & 51,75438529 & 1,064020725 & 48,64039213 & $1,9342 \mathrm{E}-68$ & \\
\hline Variable X 1 & $-0,00030997$ & $2,27476 \mathrm{E}-05$ & $-13,6262603$ & $5,5616 \mathrm{E}-24$ & \\
\hline Bottom $95 \%$ & Upper $95 \%$ & $\begin{array}{l}\text { Bottom } \\
95,0 \%\end{array}$ & $\begin{array}{l}p p p e r \\
95,0 \% \\
\end{array}$ & & \\
\hline 49,6417472 & 53,86702338 & 49,6417472 & 53,86702338 & & \\
\hline$-0,000355131$ & $-0,00026478$ & $\overline{0}, 000355131$ & $-0,0002648$ & & \\
\hline
\end{tabular}

Fig. 1. Output of the results of the regression model

As can be seen from Figure 1, the coefficient of determination $\mathrm{R} 2$ of the given model is 0.664 , or $66.4 \%$. This $\mathrm{R}$-squared value indicates that the calculated parameters of linear regression explain the relationship between the number of new infections and the price of oil by $66.4 \%$. The indicator above $60 \%$ speaks about the "good" quality of the model, however, it would be wrong to consider it "good" - for this R2 should be more than 0.8 .
As for another indicator that serves as a litmus test for the regression model - the y-intersection coefficient - in our case it is 51.75. Interpreting this result to a given model, we conclude that in the absence of new cases of corona virus infection, the price of Brent crude should rise to $\$ 51.75 /$ barrel in the medium term. This value is rather hypothetical, since the price of oil depends on many other factors not included in the linear regression model. However, the value of the coefficient clearly indicates that the oil price will not return to the previous quotations after the end of the pandemic.

Finally, the coefficient of the variable $\mathrm{x}$, equal to- 0.0003 , represents the weight of the variable $\mathrm{x}$ on $\mathrm{y}$. In our case, the number of new cases of corona virus infection affects the price of a barrel of Brent crude with a weight of -0.0003 , which indicates a small degree of influence. The negative sign of the coefficient is more important in this model, since it demonstrates the unambiguous inverse effect of the parameter $\mathrm{x}$ on $\mathrm{y}$ : the newer infections, the lower the price.

Let us move on to correlation analysis. This economic and statistical method helps to find out the presence or absence of a relationship between the sample indicators. In our study, correlation will find out whether it is possible to predict the value of another parameter based on the value of one variable. The results of the correlation analysis carried out using MS Excel are shown in Figure 2.

\begin{tabular}{llll}
\hline & \multicolumn{2}{l}{ Column 1 } & Column 2 \\
\hline Column1 & 1 & & \\
Column2 & - & 0,81479786 & 1 \\
\hline
\end{tabular}

Fig. 2. Conclusion of the results of correlation analysis

The correlation coefficient, ranging from -1 to 1 , in this model is -0.8148 . This value on the Chad dock scale indicates "_c sign, in turn, demonstrates the inverse relationship. Such a high value of the correlation coefficient proves the statistical significance of the influence of the number of new cases of corona virus infection on the price of a barrel of Brent oil. The proven dependence allows us to turn to the combined correlation-regression analysis, implemented using a scatterplot and plotting a trend line in MS Excel (figure 3).

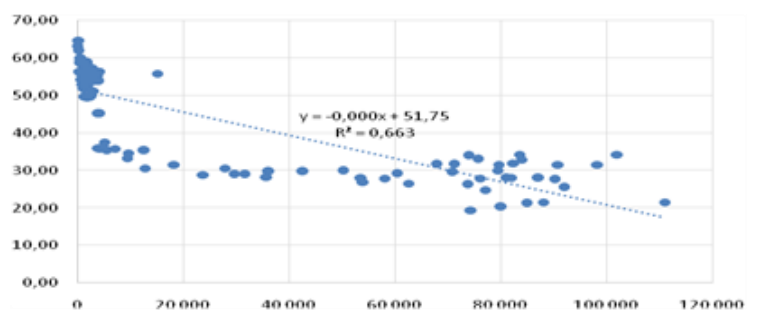

Fig. 3. Linear Regression Model

Looking at Figure 3, it becomes clear why the coefficient of determination of the regression model was at a level less than 0.8. Linear regression does not fully reflect the relationship between the indicators in the given model, and this is due to the fact that the dynamics of the number of new cases of corona virus infection in world is exponential.

By selection graphically, looking at the R-square value, we find that the logarithmic regression model $\left(y=b^{*} \ln (x)+a\right)$ 
most accurately reflects the relationships between the number of new cases of corona virus infection and the oil price. The results of the correlation and regression analysis are shown in Figure 4.

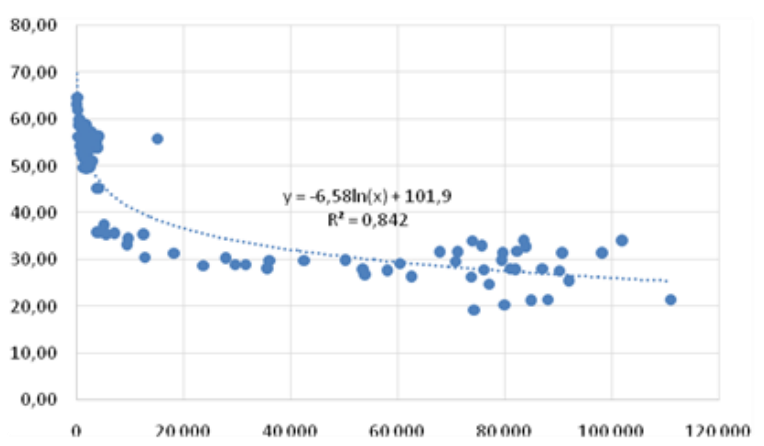

Fig. 4. Logarithmic Regression Model

Figure 4 shows that the logarithmic function most closely follows the location of the elements of the regression model. In addition, the value of the coefficient of determination of the logarithmic model is the highest, which means that it is this model that reflects the relationship between the number of new cases of corona virus infection and the price of oil. The quality of the described model is $84.3 \%$.

The explanatory variable coefficient in this model cannot be determined directly by looking at the equation. However, through several logarithmic transformations, it is possible to establish that with an increase in $\mathrm{x}$ by $1 \%$, y grows by $-6.587 /$ 100 units. Note that the above model is the leas common semi logarithmic model, since the logarithm is only available for $\mathrm{x}$.

\section{RESULTS AND DISCUSSION}

Correlation-regression analysis allows us to draw the following conclusions about the peculiarities of the development of the world oil market during the corona virus pandemic:

- the price of oil has acquired a high negative dependence on the number of newly infected with corona virus infection;

- even in the context of the recovery of financial markets after the pandemic, the oil price in the medium term will not rise above $\$ 50 /$ barrel;

- the dependence of the price of Brent oil on the number of newly infected COVID - 19 is semi-logarithmic;

- the weakening of demand for energy resources, caused by quarantine measures and supported by the surplus of supply formed even before the crisis, even if the OPEC + market is regulated, will collapse oil quotes for a long time.

\section{CONCLUSIONS}

The results of the analysis of the impact of the corona virus pandemic on the world oil market and the decisions of OPEC + adopted in 2020 indicate a major transformation of the world oil market. If 5 years ago, economists warned of an impending energy crisis, now in 2020 the world is facing an unprecedented consumption crisis. The geopolitical games of the exporting countries have led to an excess of supply in the oil market. The corona virus pandemic has forced to reduce oil consumption in the transport industry - the main buyer of energy resources - by $80 \%$. Under these conditions, the main goal of the oil producing countries is to prevent the full filling of oil storage facilities in the world.

The negative impact of the spreading corona virus pandemic on the oil market is becoming threatening. The next season of disclosure of corporate reporting will demonstrate to shareholders significant losses of oil producing companies. As a result, many investors will leave the oil industry and most small and medium-sized oil producers go bankrupt. The resulting surplus of supply will force countries to resort to conservation of wells, which will be accompanied by significant costs. All this will lead to a colossal recession in the world economy.

Even taking into account the planned value of $\$ 40 /$ barrel, Russia lost more than 2 trillion dollars of export in MarchApril. Considering that the demand in the oil market has dropped by $30 \%$, the oil price will continue to fall. A possible second wave of the spread of the corona virus under these circumstances could reduce the aggregate demand for oil to 20 mbd (million barrels per day), while in the fourth quarter of 2019 this figure was $100 \mathrm{mbd}$. Thus, the second wave of infection, if it occurs, will lead to a deep recession in the Russian oil-dependent economy.

The current situation significantly reduces the role of oil in the geopolitical arena, gradually turning it into an ordinary exchange commodity. Even with a rapid showdown in the spread of corona virus infection, oil prices can actually drop to zero. Rapid loading of oil storage facilities can lead to a forced shutdown of oil production in a number of countries. In view of the almost complete lack of the ability to directly regulate the market, it is likely that OPEC will outlive itself and cease to operate long before the end of 2022, before which the last OPEC+ agreement was concluded. The transformation of the world oil market, thus, will serve as the basis for the transformation of oil-dependent economies, including Russia, towards the development of their own production facilities and the knowledge industry.

\section{REFERENCES}

[1] V.V. Bushuev, A.A. Konoplyanik, and Ya.M. Mirkin, Oil prices: analysis, trends, forecast, monograph, M.: Publishing House "Energia", 2013, $173 \mathrm{p}$

[2] A.O. Goryacheva, and E.V. Grushevenko, "Assessment of the Impact of Potential Shocks on the World Oil Market Using the Model for Forecasting the World Oil Market”, Oil, Gas and Business, no. 5, 2013, pp. 37-42.

[3] "Dynamics of Brent crude oil prices for 2020", Calculator reference portal, 2000-2020, URL: https://www.calc.ru/dinamikaBrent.html?date $=202013$

[4] "The IMF assessed the depth of the fall of the Russian economy in the context of a pandemic", Official site of JSC Business News Media, 1999-2020, URL: http://www/vedomosti.ru/economics/articles /2020/04/14/827991-mvf-otsenil-padeniya-rossiiskoi.27

[5] "OPEC + ministers agreed to cut oil production. What does this mean", Official site of JSC "ROSBUSINESSCONSULTING", 1995-2020, URL: https://quote.rbc.ru/news/article/5f3d48279a 79477debacc3d

[6] "Oil and gas production and oil refining industry: trends and forecasts. Results of 2019", Analytical bulletin "RIA-Raiting”, M., 2020, 52 p.

[7] "OPEC and OPEC +: balancing the world oil market", Energy Bulletin, no. 75,2019 , URL: https://ac.gov.ru/archive/files/publication/a/ 23695.pdf

[8] "Forecast of energy development in the world and Russia until 2040", Institute of Energy Research RAS, Analytical Center under the Government of the Russian Federation, URL: https:// www.hse.ru/data/2014/01/23/1325658082 / prognoz-2040.pdf. 
[9] "Coronavirus statistics", CORONAVIRUS website (COVID-19), 2020, URL: http://coronavirus-monitor.u/statistika/

[10] "Global Energy Perspective 2019: Reference Case", MCKinsey\& Company,
1996-2020,

URL: https://www.mckinsey.com/industries/oil-and-gas/our-insights/gobalenergy-erspective-2019 